\title{
Examining the Role of Chinese Diaspora Media During the COVID-19 Pandemic: The case of Sing Tao US 'Current Events Observation'
}

\author{
Zhang Fengyuan \\ The Chinese University of Hong Kong, Hong Kong, China
}

\begin{abstract}
The aim of this study is to understand the role of Chinese diaspora media in the US during the COVID-19 period. The study focuses on the Sing Tao YouTube channel, a program named "Current Events Observation". In order to understand the role of the Chinese diaspora media, this study selected the data from January 2020 to May 2020 from this program. Critical Discourse Analysis (CDA) and Content Analysis were adopted to analyze the data. It took a social constructivist approach, applying concepts to analyze the media representation of the selected case during COVID-19. According to the analysis, there are three main findings. First, the media representation of Sing Tao YouTube channel focuses on the shared fear/concern of the Chinese diaspora, namely, the racial discrimination against the Chinese diaspora. In particular, concerns about the boycott of stigmatized words and incidents of racial discrimination and violence against American Chinese during the pandemic. Second, a binary between the US and China was constructed in the media coverage of the pandemic. Such a binary setting not only implies the ambivalence of the diaspora identity but also reveals the diaspora media's political position. Finally, the Sing Tao, as a diaspora media also attempts to construct synchronicity and a sense of belonging across geographic borders between the Chinese community in the US and the homeland through commenting on Chinese entertainment shows. This study contributes to the understanding of the complex interplay between the diaspora media and the ambivalent identities of the Chinese diaspora in the context of a global crisis of COVID-19.
\end{abstract}

Keywords: Diasporic media, Chinese diaspora, media representation, Sing Tao US

\section{Introduction}

\subsection{Background}

Ethnic minorities living overseas have their media, and these media are their voices and bond of connection. Compared with mainstream media in the host society, Chinese diaspora media usually report in Chinese (Mandarin or/and Cantonese). The language is considered as an advantage of the Chinese diaspora media because it becomes the primary information source for the Chinese speaking diaspora in the US. Zhou and Cai (2002). As the President of Sing Tao News once noted, it is a newspaper of "nostalgia". Such comments vividly capture the relations between diaspora media and the identity of diaspora. With the diversification of

\footnotetext{
${ }^{1}$ https://youtu.be/3ruD677rj0o
} 


\section{Ecrhs}

\section{4th International Conference On Research In} HUMANITIES \& SOCIAL SCIENCES

media forms, information interaction is no longer limited to paper media. Chinese diaspora media actively explore new channels of communication in the era of mobile Internet, comprehensively deploy websites, social media, and mobile clients, and further transform into integrated media so a large number of people can participate in discussions. Mansell (2010) argues that technologies can overwhelmingly change cultural and political life with consequences for identity and citizenship. With the development of communication technology, ethnic minorities have the right to speak out.

The United States is a place with many Chinese immigrants. According to the latest Asian-Pacific descent data released by the Federal Census Bureau in May 2018, the Asian-Pacific descent population in the United States has reached 21.4 million, of which the Chinese population exceeds 5.08 million, mainly in large cities in New York or California. The Chinese community has become a force that cannot be ignored in American society. The Chinese diaspora media has a certain degree of influence on the region. Only if we examine the media content produced by Chinese diasporic media, Sing Tao as an example, can we begin to understand the broad significance of media and communication to the cultural and political representation and sense of belonging of minorities (Georgiou, 2013). Especially during the COVID-19 period, many Chinese diaspora media are reporting and commenting on related events. For instance, the COVID-19 situation in China and the world, and the political struggles that occurred during this pandemic period. Then, what is the role of Chinese diaspora media during this period? For instance, how the identity of the Chinese diaspora is constructed on a specific Chinese diasporic media in the US and how it is related to the global political context?

This article will take the column involving COVID-19 in Sing Tao's YouTube platform which is one of the most influential Chinese media (Sing Tao News) in the United States as a case to explore the role of the Chinese diasporic media in the US during the period of COVID-19. According to Sing Tao News Corporation Limited official website ${ }^{2}$, Sing Tao News Corporation Limited is a media corporation with a vision to become a leading content and service provider serving global Chinese communities. The "Sing Tao" brand dates back to 1938 when the daily newspaper of the same title was launched in Hong Kong. Within the Media operations, the flagship publication is the renowned Chinese international newspaper Sing Tao Daily, which is one of the world's most widely read Chinese newspapers. Over the years, "Sing Tao" has become recognized as a global name in the print media market. In addition, Sing Tao Daily is the first Chinese newspaper in Hong Kong to develop overseas. Leveraging on the strength of the brand, the Group's business has extended to a comprehensive portfolio ranging from free newspapers to magazines and digital media. Based in Hong Kong and with a business network covering major cities of the PRC, the US, Canada and Europe. There are branches of Sing Tao in major cities such as New York, San Francisco, and Los Angeles in the US. Among them, "Sing Tao Daily" (Western US edition) was founded in 1975 and is headquartered in San Francisco. It is the best-selling Chinese newspaper in the western part of the United States, and its circulation exceeds the sum of all other paid Chinese newspapers in the area. Besides, Sing Tao Tv YouTube channel was established in 2013. It provides diversified programs such as news, current reviews, travel, food and life information.

\footnotetext{
${ }^{2}$ Sing Tao News Corporation Limited official website: https://www.singtaonewscorp.com
} 


\section{icrhs}

\section{4th International Conference On Research In}

HUMANITIES \& SOCIAL SCIENCES

The name of "Coronavirus Disease 2019 (COVID-19)" refers to a novel coronavirus which is caused by the novel severe acute respiratory syndrome coronavirus 2 (SARS-CoV-2) that happened in 2019. A novel coronavirus, initially reported in Wuhan, China has resulted in an ongoing outbreak starting from late December 2019. The World Health Organization (WHO) has announced that the situation has become a pandemic on 31 January of 2020. As of July 1 , 2020, COVID-19 has affected more than 200 countries, resulting in more than 10 million identified cases with 508000 confirmed deaths. On January 20, 2020, the first case of COVID-19 infection in the United States was discovered in Washington State. By March 17, the virus or COVID-19 had spread from several states in Washington, New York, and California to all 50 states. At present, the total number of global cases in the United States has exceeded 7 million, which is the country with the largest number of reported cases, accounting for about one-fifth of all reported infections.

In particular, this work proposes to answer the following research questions:

\subsection{Research Question}

What is the role of Chinese diaspora media in the US, as Sing Tao an example, during COVID-19 pandemic?

1.1.1 How Chinese diaspora media in the US represented facts and shared their comments during the COVID-19 period?

1.1.2 During the COVID-19 period, how does the Chinese media framing content and what political orientation it attempts to bring?

1.1.3 What kind of discourse does Chinese diaspora media construct and how to connect it with the identity of the diaspora community?

\section{Literature review}

In order to understand the role of Chinese diaspora media, we need to build an understanding of the key concepts adopted in this study. In this section, I will firstly discuss the concept about identity, diaspora, diaspora media, media representation, and discourse in order to explore the role of Chinese diaspora media during the COVID-19 period. The aim is to construct the conceptual framework for analysis. These concepts are not separated but are interconnected to some extent.

\subsection{Identity}

Firstly, we need to talk about the term "identity". The definition of identity given by Haralambos and Holborn is that "the sense that someone has of who they are and of what is most important about them" (2013, p.729). It plays a crucial role in making comparisons between people and establishing similarities and differences between them. Therefore, how to distinguish "the self" and "the others" is the key point to this concept here.

Identity is a complex and highly contested concept. It can be classified into three categories of western writings, biological view, structuralist, and post-structuralist approach since the 19th century. From the social constructivism like Calhoun pointed "a construction no matter how 


\section{Ecrhs}

\section{4th International Conference On Research In HUMANITIES \& SOCIAL SCIENCES}

much it feels like a discovery" (Calhoun,1994, pp.9-10). From a poststructuralist view, As Hall pointing out identity does not "signal that stable core the self" (Hall,1996, p.17). Extensively draws on Foucault, it argues that subjects or identity are produced in dominant discourses thus identities are the "ideological constitutions of the self" (Howard, 2000, p.368). Therefore, we need to pay more attention to the reflexive approach. A reflexive approach of identity stresses the sense of belonging and continuity especially in media study (Georgiou, 2006).

Identity and diaspora are interconnected. Diasporic identity is defined by recognizing the necessary differences and diversity. They constantly change themselves along the route of migration, but at the same time love to recreate the endless desire to return to the "lost origin" (Hall, 1994). I will discuss the concept of diaspora and situated in media context in the next subsection.

\subsection{Diaspora and diasporic media}

In recent years, many scholars have turned their attention to the study of the Chinese diaspora. The term diaspora can be defined in several ways. Clifford points out that diaspora is a traveling term (Clifford,1994). Despite its common reference to the history of the exile of the Jews, nowadays the "diaspora" has been used in many fields on identity, ethnic relations, migration. Moreover, transnational connections are challenged by new media platforms. Such as Cohen states that the diaspora can be held tighter or recreated through the mind, through cultural artifacts and through a shared imagination under nowadays network-world $(1997,26)$.

Some authors argue that ethnic or diasporic groups are said to adopt strategies to challenge the dominant discourse and make their voices heard (Cottle, 2000; Alia and Bull, 2005; Karim, 1998; Chan 2005; Van Dijk, 2000). However, diasporic media is not only a "weapon" to struggle with negative portrayal but also to construct the identity (Gloria Macri, 2011). Building on Habermas' public sphere, Dayan (1998) views that diasporic media and communication are of key importance in which diasporic identities are constructed and re-constructed.

Yang believes that in the Internet-based Chinese cultural space, the Chinese language is the main mode of communication in most of these spaces. China-based streaming media is the source of the true Chinese identity of immigrant netizens. When unity is implied through a common language, culture and political views, the awareness of authentic Chinese is maintained and strengthened among immigrant netizens (Yin, H., 2015.) the diasporic media has a dual nature, which can promote the integration of immigrants into host society while maintaining ethnic culture and identity (Zhang K and Hao X, 1999).

\subsection{Media representation and discourse}

Media representations are how the media portrays particular groups, communities, experiences, ideas, or topics from a particular ideological or value perspective. In a highly mediated world, media plays a crucial role in human life and "influence not what people think, but what they about" (Kaye, 2001). What is more, with the development of communications technologies (ICTs), ranging from more traditional telephony to satellite TV, and most recently, the Internet (Bernal, 2005; Hiller and Franz, 2004; Parham, 2004; Sinclair and Cunningham, 2000; Sun, 2002; Vertovec, 2004), the continuous expansion of media makes the media representations a crucial part in our daily life. We cannot escape the media. They are involved in every aspect of 


\section{icrhs}

\section{4th International Conference On Research In}

HUMANITIES \& SOCIAL SCIENCES

our everyday lives (Silverstone,1999). Besides, the meaning is produced within representation through language, image and symbols and it "is what gives us a sense of own identity, of who we are and with whom we 'belong"' (Hall, 1997, p3).

However, it is not an innocent process. Representation could be regarded as the process of constructing meaning through the exercise of symbolic power (Hall, 1997, pp.183-226). That means media representation is a kind of symbolic power. And the media power is exercised symbolically (Castells, 2009, P.416). Yet, the dominant media representation, as well as identity, constituted within could be challenged by an alternative representation system. "The new processes of domination to which people react are embedded in information flows, the building of autonomy has to rely on reverse information flows" (Castells, 2004, p.69). Besides, the process of exercising symbolic power is not equal. Mainstream media representation often trends to reinforce and reproduce the existed power-relations with society. Social reality is represented from a preferred view, from selected discourses, from power struggles behind. In this research, the Chinese diaspora media has the symbolic power to construct the ideas and thinking of the Chinese diaspora on a certain topic during the COVID-19 period.

\subsection{Contextualizing identity, Chinese diaspora and media in the US}

The Chinese-language press in the US traces its origin to two publications: Golden Hill News started in San Francisco in 1854 and the Oriental in 1856 (Miller, 1987: 27-8). After the 20th century, Chinese media has flourished in the United States (Shi, Y., 2009). The Chinese Language Media in the US connects immigrants to their host society. The rise of Chinese language media symbolizes the diverse lives of Chinese immigrants living in the United States(Zhou and Cai 2002).

Chinese diaspora media has been investigated by many scholars in the past decades. Many scholars (Sun, 2015; Wong, 2017; Lin and Song, 2006) who study this topic are discussing based on traditional media such as newspapers, yet relatively few scholars focus on online programs as research texts to study the relationship between identity, diaspora and media. However, with the change of people's behavior and habits, newspapers are no longer the mainstream (Meyrowitz, J., 1986) and the Internet has instead become the main platform for information exchange and sharing. Moreover, with the emergence of the COVID-19 pandemic, are there any new insights regarding the media representation of Chinese diaspora identity in the US?

Not only Sing Tao Daily, but many media have also opened up online channels in other ways to expand their influence. I will discuss the program based on Sing Tao's YouTube platform, which can make up for the deficiencies of the predecessors that have not been involved in the emerging platform. In the new context of COVID-19, what role would Chinese diaspora media play? Since it happened in a new context, fewer scholars are discussing this part, which is also the source of my research questions. 


\section{Ecrhs}

\section{4th International Conference On Research In}

HUMANITIES \& SOCIAL SCIENCES

7-9 May 2021

Milan - Italy

\section{Methodology}

This paper is a case study of the "Current Events Observation" program of Sing Tao US on the youtube channel. The reason why I use case study analysis there is that in a specific context and cannot be controlled by humans, case study analysis can better understand and explain my research questions and results. As Yin points out a case study is a preferred strategy to answer the "how" or "why" question while the focus of research is on a context-specific contemporary phenomenon that the research has no way to control (1994:1). Here, the case study can help us to better understand the role of Chinese diaspora media during the COVID-19 and the relationship between the political factors behind the concept of identity and the media text. As Tellis suggests that case study is a particularly useful methodology in an in-depth investigation (1997). I choose Sing Tao because it is one of the largest Chinese media in the US with an influence on the Chinese community. The program is selected for its richness in the information. Meanwhile, as a commentary column, it reflects the attitude of Sing Tao to a certain degree.

Media content was obtained through the “Current Events Observation” ( 时事观察 ) program of Singtaotv YouTube channel. Based on key Chinese words such as pandemic (疫情), coronavirus( 冠狀病毒), and Novel Coronavirus( 新冠肺炎 ) as a filter, I selected 24 columns of Sing Tao "Current Events Observation" program content from January 22 to May forth, and converted the text in the video verbatim into text form, and then analyzed it. The content I selected is sufficient to analyze.

I use Content Analysis and Critical Discourse analysis (CDA) as methods to analyze the data. Content analysis is a suitable method that can analyze a large number of text data. Besides, I also use the CDA method because of considering the depth of my research questions. Fairclough points out that CDA can systematically explore often opaque relationships of causality and determination between the texts. CDA is not only attempting to show how discourse is shaped by power relations and ideologies but also try to construct identities, social relations and systems of knowledge (Norman Fairclough, 1995). The paper is to explore the role of Chinese diaspora media and the meaning of how media construct identity and the political relationships during COVID-19. As this paper concerns the relationship between the identities of the Chinese diaspora in the US and media representation of the COVID-19, CDA is considered necessary to explore the depth of the data.

\section{Findings and Analysis}

\subsection{Shared fear or concern: Against Racial Discrimination}

\subsubsection{From "Wuhan pneumonia" to "COVID-19"}

The selection of specific nouns is important for constructing meaning. Based on the collected text content, the most significant feature I observed was the change in terms of naming the pandemic. At first in January, the Sing Tao media called the pandemic as "Wuhan Pneumonia" or “Wuhan pandemic” (武双腅/武双疫情), but since the report in early February, the wording on the pandemic of Sing Tao was changed from "Wuhan Pneumonia" to "Novel 


\section{icrhs}

\section{4th International Conference On Research In HUMANITIES \& SOCIAL SCIENCES}

Coronavirus"(新冠做炎疫情). The change of naming the pandemic on the media representation of Sing Tao is not only related to human's understanding of the new virus, in this context, but it is also more related to the shared situation of the Chinese in the United States.

Since the outbreak started in Wuhan, Chinese and foreign media used "Wuhan pneumonia" to report earlier. It was not until February 11 that the World Health Organization (WHO) officially named pneumonia as COVID-19, that this emerging disease had an official English name, and emphasized that the naming will not specifically refer to a certain geographic location, any animal, or human individual or groups. The initial use of "Wuhan Pneumonia" was not considered as a stigma to the Chinese or China as it only signals the place of the outbreak. However, since the WHO officially changed its name, many western media insist on using "Wuhan pneumonia" and even "Chinese virus".

For example, "The Herald Sun" and "The Daily Telegraph" in Australia, the "USA Today" in the United States and German news and current affairs best-selling magazine "Der Spiegel", "Sunday Mirror" of Ireland, "Jullands-Posten" of Denmark, so on so forth, referred to COVID-19 as China/Chinese virus (中国病毒), Wuhan virus /pneumonia (武汉病毒/肺

炎), with serious prejudice and discrimination. Even on March 17, 2020, this severely prejudiced and discriminatory name appeared in the personal Twitter of US President Trump (Figure1). On the contrary, Sing Tao, the Chinese diaspora media changed the naming of the pandemic as soon as a more scientific and neutral word available. It suggests that the diaspora media is aware of the negative connotation conveyed by 'Wuhan pneumonia' or 'China virus' and its risk to intensify the long-existing racial discrimination the Chinese community suffered in their host society.

Sing Tao commentator Chen Yingjie expressed that the name of "Chinse virus" can expand the Anti-Chinese sentiment:

"Trump remarks that the Chinese virus has continuously expanded anti-Chinese sentiment and will have a great impact on the anti-Chinese phenomenon in mainstream society in the future. Because of the presidential election, we must choose a president who is considerate and tolerant of each other and considers the overall situation."

(Chen Yingjie, "Current Events Observation” program, March 24, 2020)

Such comments reveal the ambivalence of the diaspora identity between the host society and the homeland. For the Chinese diaspora in the US, China as the country of origin or the homeland, cannot be easily changed in the eyes of others in the host society. The stigmatization of China also closely affects the Chinese diaspora in the US. The discrimination caused by naming the pandemic stigmatization may affect every aspect of the everyday life of the Chinese diaspora, not only the prejudice against China due to stereotypes, but also the occurrence of some truly discriminatory violence. 


\title{
Eorhs
}

\section{4th International Conference On Research In} HUMANITIES \& SOCIAL SCIENCES

\author{
Figure 1 U.S. President Donald trump's comments on his Twitter \\ Donald J. Trump \\ (drealDonaldTrump
}

The United States will be powerfully supporting those industries, like Airlines and others, that are particularly affected by the Chinese Virus. We will be stronger than ever before!

\subsubsection{Discriminatory violence}

A wave of racism that discriminates against Asians caused by the COVID-19 is intensifying. During this period, violence based on racism occurred frequently in the US, and Asian groups suffered severe personal attacks. Through interviews and analysis of American media reports, the BBC found that there have been more than 100 incidents suspected of targeting Asians in the United States since January. Seventy percent of the cases are related to the new crown virus, and $40 \%$ have been reported to the police. Besides, from March 19th to April 1st, the American non-profit organization "Stop Hating Asians" received more than 1,100 reports of hate incidents.

Extracts from the Sing Tao program stressed that discriminatory violence had had a serious impact on Chinese diaspora and even Asian in the US:

"The headline of a French newspaper is a Chinese woman wearing a mask, with a yellow headline warning, yellow peril around you?"

"Chinese-British people are discriminated against by bus"

"The Japanese store says, 'no Chinese'."

"Chinese people wearing masks were verbally abused, accused, and even beaten"

"In Brooklyn, New York, a woman of Chinese descent was splashed with acidic liquid when she was going out to take out the trash, causing extensive burns to her face and neck.

"A bully beat an Asian classmate on the head more than 20 times, accusing him of the virus and telling him to "roll back to China"

The words about "yellow peril", "no Chinese" and "roll back to China" so on so forth, reflect the unfair treatment received by the Chinese diaspora in the US. Discrimination can lead to the destabilization of society, especially in the face of infectious diseases. Although Western countries have been committed to the demonization of Chinese or Asian descendants since ancient times (Gover et al., 2020), the emergence of COVID-19 has led to more discrimination and violence worldwide. These negative expressions and words not only unveil the long-lasting racial discrimination against migrants in the host society but also hint at the risk of intensified racial violence during the pandemic. The consequences of racism are complex. It has an impact on people's self-esteem, self-identity, and self-confidence.

\subsubsection{Donald Trump smears China, Sino-US relations are strained}

In addition to prejudice against China, the so-called choice of words also carries certain political implications. US President Trump often uses stigmatizing words to describe China. This stigma against China often appears on social media in various forms, which is not conducive to the development of Sino-US relations. 


\section{Ecrhs}

\section{4th International Conference On Research In}

HUMANITIES \& SOCIAL SCIENCES

Like Sing Tao commentator Huo Yongqiang once said in a program:

"Trump has repeatedly used the 'Chinese virus' to discredit China. It is obvious that he has seen the pandemic out of control and tried to transfer the problem to China." Huo Yongqiang, "Current Events Observation" program, March 25, 2020)

The word "Chinese virus" connotates not only racial discrimination but also Trump's contempt of China. Adding the word "Chinese" to the front of the virus means that China is responsible for COVID-19, and the responsibility is shifted to China. This stigmatized vocabulary will deepen racial discrimination in the West against Chinese people and even Asia. Furthermore, in the program on March 24, 2020, Sing Tao commentator Chen Yingjie also expressed similar views. Sino-US relations have been very tense since Trump was elected President of the United States. What is more, the arrival of COVID-19 has exacerbated this phenomenon. Some phrases like "Chinese virus" are manifestations of stigmatization of China. During this pandemic, apart from racial discrimination against the Chinese diaspora in the US, behind it was the competition between Chinese and US political forces.

Since the outbreak of COVID-19, a group of US politicians, including the US President, Secretary of State, and members of the Senate and House of Representatives, have frequently used discriminatory terms such as "Chinese virus" and "Wuhan pneumonia" to concoct "The virus originated from the Wuhan Institute of Virology" and "China is spreading the virus to the United States" and other remarks according to BBC News.

Besides, the Sing Tao commentator Huo Yongqiang expressed his dissatisfaction that the US President has no sense of crisis in the face of the COVID-19. He pointed out that: "Trump (to COVID-19) has no sense of crisis. His only sense of crisis is whether he can be re-elected. What we need is a president who will take us to fight the epidemic." Such expressions indicate the negative attitude towards the Trump administration during the pandemic. To a certain degree, as a leading diaspora media, such comments have the potential of affecting its audience in terms of the US presidential election. I will discuss this point in detail in the next subsection.

The anti-China remarks made by some US media and politicians have fueled public xenophobia and racial discrimination, leading to an increase in verbal and physical attacks on Chinese diaspora and even Asian groups, making them become the most vulnerable targets. For example, on February 3, the Wall Street Journal published a commentary article titled "China Is the Real Sick Man of Asia", discrediting the efforts of the Chinese government and the Chinese people to fight the pandemic. Besides, at the White House press conference, a government official called the "Kung Fu flu" in front of a CBS Chinese reporter.

Politicizing the pandemic will not only be detrimental to global epidemic prevention and control but will cause serious secondary disasters. In human culture, there is widespread fear of death and anxiety about health. Especially when facing infectious diseases, people will use prevention and control to rationalize their discrimination and hostility. Group anxiety, panic, and restlessness can stimulate overreaction. Certain groups and certain countries will be victims of overreaction to the pandemic. 


\section{icrhs}

\section{4th International Conference On Research In}

HUMANITIES \& SOCIAL SCIENCES

\subsection{Setting the binary: the US vs China}

US and China use different solutions to combat the COVID-19. The text material collected from Sing Tao reflects the diaspora media's appreciation of China's governance measures during the pandemic, the criticism to the US and of US President Trump.

\subsubsection{Praise China for its response to the COVID-19}

Sing Tao commentator Yu Fei gave a positive comment on the fight of China against the COVID-19:

"China's information is transparent, it is dedicated to responding to the pandemic, has benevolent doctors, has a medical team with faith and professionalism. China resolves difficulties with determination, will, perseverance, and concentration." (Yu Fei, "Current Events Observation" program, January 27, 2020)

As the commentator said, at the end of January, when the pandemic was announced to spread from person to person, China responded quickly. And "China has shown that China is a responsible country with actions." Such words and phrases like "determination", "perseverance", "focus", "information transparency" and "a responsible country" are all positive words of praise. From these words, we can see the positive promotion of China's fight against the epidemic in their media coverage.

"China has to deal with both domestic and foreign situations in fighting the COVID-19....this COVID-19 is facing domestic and foreign pressure, coupled with a huge population and very suffering. As the people, do not be led by the Chinese and foreign media, and respond calmly to the pandemic... Under these two pressures, China has done a good job in this tough battle." (Yu Fei, "Current Events Observation" program, March 02, 2020)

According to the above comments, faced with the dual pressure of controlling the pandemic at home and the external need to deal with economic and trade pressures, China still controls the pandemic well and won praise from the world. A phrase like "done a good job" express the praise of China. Furthermore, the sentence "People should not be led by and should respond calmly" refers that the diaspora media wants the US Chinese diaspora can have their judgment in the mixed information. Let everyone see that China has demonstrated a strong sense of responsibility and contributions in the face of the pandemic. Such comments from the media representation can be considered as an attempt to guide the audience to express a good impression of China's behavior and action.

\subsubsection{Criticize the U.S. attitude and solutions in COVID-19}

The number of newly diagnosed cases increased by over 10,000 every day, becoming the world's most...more than two months after the first confirmed case of the COVID-19 in the United States, the pandemic has spread to all parts of the United States, with more than 200,000 infections and nearly 4,000 death. (Huo yongqiang, "Current Events Observation" program, March 25, 2020) 


\section{Ecrhs}

\section{4th International Conference On Research In HUMANITIES \& SOCIAL SCIENCES}

On the contrary, the evaluation of the United States is relatively negative, which is in sharp contrast to the praise of China. Several commentators of Sing Tao pointed out that the US pandemic is serious. Due to the initial relaxation of the people and the government on COVID-19, the effectiveness of pandemic prevention in the United States is very poor. Furthermore, the commentators of Sing Tao gave negative comments on the United States are more of criticism of the Trump administration. In January and February 2020, as the outbreak hit China's manufacturing sector and began to cause huge losses in Italy, Trump has repeatedly downplayed his threat to the United States. After the first few U.S. cases appeared, Trump and other government officials stated that the situation has been brought under control and will dissipate "like a miracle" in the summer.

In addition, in response to Trump's previous remarks about the lifting of the ban in April, Sing Tao commentator Huo yongqiang said that "Trump is eloquent and has integrity issues." Furthermore, Chinese Americans in the United States have the right to vote. According to BBC, Asian Americans are the fastest-growing ethnic group in the United States, with more than 11 million registered voters. In many swing states, the Asian population exceeds 5\%, which is enough to affect the election. According to a September poll conducted by the "Asia Pacific Americans Data" organization, among Chinese Americans, 56\% expressed support for Biden, $20 \%$ preferred to vote for Trump, and another $23 \%$ answered that they did not know who would vote for. Sing Tao commentators criticized Trump's response to the COVID-19, which may affect the direction of audience voting. According to a New York Times report, one of the Chinese voters said that "I was not keen on politics at first, and I never thought about voting," she said. "But the discrimination against Asians during the epidemic and the Trump administration's immigration policy against Chinese made me decide to vote for Biden."

\subsubsection{Summary}

When Diaspora Media uses media coverage to create a good image of China and a bad image of the United States, it may affect the audience in certain ways. Identities of the Chinese are ambivalent. As a Chinese diaspora in the United States, they are both American and Chinese and care about what is happening in the United States as well as what is happening in China. Culture is formative in the composition of social and political life, and the media constitutes the mechanism and system represented in culture (Hall, 1996). In other words, the identity we identify with is not given naturally, but formed in the media, and is the right to tell stories or shape the position of certain topics (Shi, 2005). Hence, the role of media is significant and the framework and perspective created by the Chinese diaspora media are very important.

Besides, the content produced by the media may affect the judgment of the Chinese in the United States to some degree. The biggest influence of a media is not to persuade people who can think independently how to act, but its influence is exerted on a huge population so that they have a common response (Lord, 2010). The impact of news on the audience is gradually expanded from affecting a person, a family and a unit to affecting a large number of people, from affecting individuals to affecting the group and even the public, making a large number of audiences and even the whole society has undergone certain changes. It also involves political issues. When the media keeps suggesting a certain political position, people will respond to it. This is the product of human thinking under the influence of political information, which is 


\section{iorhs}

\section{4th International Conference On Research In}

HUMANITIES \& SOCIAL SCIENCES

suggestive (Neuman et al, 1993). On the one hand, it is a symbolic suggestion; on the other hand, it is the emotions and assumptions that people generate when they respond to this suggestion. The combination of the two forms a new perception of the audience.

\subsection{Beyond the geographic borders: The US Chinese community has a sense of belonging to china during the COVID-19 period}

The special period of the COVID-19 pandemic has created a condition for more people, whether they are Chinese or Chinese in the United States, to choose to stay at home. The city is blocked and the time at home is long, allowing people to choose more entertainment activities to kill time. Sing Tao commentators analyzed several popular varieties of shows and TV dramas in mainland China during the COVID-19, giving the Chinese diaspora a sense of belonging in the United States across time and space.

\subsubsection{New format of entertainment in COVID-19 pandemic — _cloud recording" in "Singers-Year of the Hits"}

"Singers-Year of the Hits" is a very popular singing competition program in China. Because of the COVID-19, it turned into a cloud competition and the response was very good”.(Huo Yongqiang, "Current Events Observation” program, March 11, 2020)

The mainland China variety show called "Singers - Year of the Hits" was originally scheduled to premiere on the seventh day of the Lunar New Year (January 31), but due to the impact of the COVID-19, it was postponed to February 7 and adopted to "cloud recording" way, innovated the way of variety shows. Especially for the final, the cloud live broadcast of Changsha, Taipei, and Tokyo will achieve a zero-time difference in music, allowing audiences to experience this "unbounded" audiovisual feast in a "zero distance". With the advancement of technology, people living in different regions can enjoy the same program at the same time. De-localization makes it easier to build a sense of belonging. Besides, Sing Tao's comments and attention on the program are also praises for China's innovative broadcasting format during the COVID-19 pandemic. It added the content reproduced by the media into the emotion of praise for China, which is implying Sing Tao's identification with China. Such attempts aim to affect their main audience, the Chinese diaspora in the US.

\subsubsection{Stay at home, watch more at home}

"Staying at home spend more time and the audience's discussion of the current drama market is always at a high level. More and more people start to watch TV series together and discuss the plot of the TV series together. For example, during the COVID-19 period, two TV dramas broadcast in China: "I will find you a better home" (安家 and "Perfect Partner” (完美关系." (Huo Yongqiang, “Current Events Observation” program, March $18,2020)$

Although the COVID-19 pandemic has restricted people's travel activities, from another perspective, the COVID-19 pandemic has created a good opportunity to connect Chinese and American Chinese through TV dramas. With the development of Internet technology, online 


\section{Ecrhs}

\section{4th International Conference On Research In HUMANITIES \& SOCIAL SCIENCES}

video platforms have become an important channel for people to watch movies. People can enjoy various movies at home without going out. The pandemic has created an opportunity for people to remove the usual tedious work, and people have more time to spend on leisure and entertainment. The Chinese in China and the United States can watch the same TV series at the same time without any time difference. For the storyline in the TV series, you can leave a comment in the comment area for interaction. Besides, watching Chinese TV dramas imperceptibly constructs a sense of belonging to the Chinese diaspora in the United States and their homeland.

Whether it is a variety of shows or TV dramas, they have become an important way for people to entertain themselves during the pandemic. The attention to Chinese entertainment shows also reflects more attention to the entertainment life of Chinese people in China. Chinese in the US like to watch Chinese urban TV dramas. Many TV dramas, such as the "I will find you a better home" (安家) and "Perfect Partner" (完美关系) mentioned above, reflect the current state of Chinese people in the workplace and daily life. Whether it is the storyline of the TV series, the filming location, or even the ad embedding, it can reflect the current development and fashion trends in China to a certain extent. Hence, it allows Chinese Americans who have stayed in the United States for a long time to better understand the status quo of Chinese people through TV dramas. By consuming the same entertainment media products at the same time as the audience in China, it constructs synchronicity beyond the geographic borders between the diaspora and their homeland. The introduction and the comments on Chinese local entertainment shows from Sing Tao firstly indicates its high attention to the homeland, China. Moreover, the synchronicity based on media consumption also serves to the construction of a sense of belonging of the Chinese diaspora and their roots.

\section{Conclusion}

The Chinese diaspora media play a significant role during the COVID-19 period. Chinese diaspora media represented and framed content about the COVID-19 and shared their comments about the homeland, the host society and the COVID-19 to their audience during the pandemic. During this pandemic, Sing Tao portrayed a beautiful image of China, and this practice is an attempt to arouse the audience's affection for China. Besides, criticism of the image of the United States will deepen their "homesickness". Therefore, Sing Tao used its media representation to construct a framework for thinking. This is the strategy of Sing Tao media and can have a long influence.

First, evidence drawn from content indicates that the change in word usage reflects that Sing Tao avoided using stigmatizing words against China. Since February, Sing Tao has stopped using "Wuhan Pneumonia" and replaced it with "COVID-19". However, after the official name was announced, many Western media still used "Wuhan Pneumonia", which is considered by the Sing Tao as a stigma to China and a manifestation of racial discrimination.

Second, a binary setting was employed in the media coverage of China and the US. When talking about China and the United States' response to the COVID-19, Sing Tao commentators expressed their affirmation of China and their dissatisfaction with the United States. Yet, the binary does not necessarily imply a denial to the host society, but a direct criticism of the 


\section{icrhs}

\section{4th International Conference On Research In HUMANITIES \& SOCIAL SCIENCES}

Trump administration's handling of the pandemic. The political tendency shown in the diaspora media's representation of the Trump administration implies the media's attempts to inform its audience to exercise their voting rights in a certain way.

Finally, the Sing Tao commentator also touched on the entertainment life of the Chinese in the United States during the epidemic. They shared and discussed several varieties of shows and TV series in Mainland China where the Chinese in the US had a high degree of discussion during the COVID-19 period. The convenience of the Internet allows Chinese in the US to overcome geographical constraints and simultaneously watch Chinese programs. The high attention paid by the diaspora media on Chinese local media products reveals the closeness of the cultural tie between the diaspora and the people in China.

This paper has certain limitations. For instance, as mentioned in the methodology section, critical discourse analysis has the problem of subjectivity. Besides, as a text-based study, it lacks the perspectives from the site of production and reception. Therefore, a further study of investigating the interplay between the media text and the audience's perception could not only test the interpretation of this research but also further reveal the dialectic relationship between the diaspora media, the identity of the Chinese diaspora community in the context of global crisis.

\section{References}

Alia, V. \& Bull, S. (2005). Media and Ethnic Minorities. Edinburgh: Edinburgh University Press.

Bernal, V. (2005). Eritrea on-line: diaspora, cyberspace, and the public sphere. American Ethnologist 32(4): 660 - 675.

Calhoun, C. (1994). Social Theory and the Politics of Identity. In C. Calhoun (ed.), Social Theory and the Politics of Identity (Blackwell, Oxford), pp. 9 - 10.

Castells, M. (2004). The Power of Identity. Malden, MA: Blackwell.

Castells, M. (2009). Communication power. OUP Oxford.

Chan, B. (2005). Imagining the Homeland: The Internet and Diasporic Discourse of Nationalism. Journal of Communication Inquiry, 29(4), 336-368.

Clifford, J. (1994). Diasporas. Cultural anthropology, 9(3), 302-338.

Cottle, S. (2000). Ethnic minorities \& the media: Changing cultural boundaries. McGraw-Hill Education (UK).

Cunningham, S., \& Sinclair, J. (2000). Floating Lives: The Media and Asian Diaspora, Brisbane.

Dayan, D. (1998). Particularistic media and diasporic communications. Media, ritual and identity, 103-113.

Georgiou, M. (2006). Diaspora, identity and the media: Diasporic transnationalism and mediated spatialities. Hampton Press.

Gover, A. R., Harper, S. B., \& Langton, L. (2020). Anti-Asian hate crime during the COVID-19 pandemic: exploring the reproduction of inequality. American journal of criminal justice, 45(4), 647-667.

Habermas, J., Lennox, S., \& Lennox, F. (1974). The public sphere: An encyclopedia article (1964). New German Critique, (3), 49-55. 


\section{icrhs}

\section{4th International Conference On Research In}

HUMANITIES \& SOCIAL SCIENCES

Haralambos, M., \& Holborn, M. (2008). Sociology: Themes and perspectives. HarperCollins UK.

Hall, S. (1994). Cultural Identity and Diaspora. Colonial Discourse and Postt-Colonial Theory. Ed. by Patrick Williams and Laura Chrisman, $392-403$.

Hall, S. (1996). Who Needs Identity? In S. Hall \& P. Du Gay (Eds.), Questions of Cultural Identity (pp. 1 - 16). London: Thousand Oaks.

Hall, S. (1997). Representation \& the media.

Hiller, HH, Franz, TM. (2004). New ties, old ties and lost ties: the use of the Internet in diaspora. New Media \& Society 6(6): $731-752$.

Howard, J. (2000). Social Psychology of Identities. Annual Review of Sociology, 367 - 393.

Karim, K. H. (1998). From ethnic media to global media: Transnational communication networks among diasporic communities. University of Oxford. Transnational Communities Programme.

Kaye, R. (2001). An analysis of press representation of refugees and asylum-seekers in the United Kingdom in the. Media and migration: Constructions of mobility and difference, 8 , 53.

Lin, W. Y., \& Song, H. (2006). Geo-ethnic storytelling: An examination of ethnic media content in contemporary immigrant communities. Journalism, 7(3), 362-388.

Lord, C. S. (1922). The young man and journalism. Macmillan.

Mansell, R. (2010). The life and times of the Information Society. Prometheus, 28(2), 165-186.

Macri, G. (2011). Logging into diaspora: Media and online identity narratives among Romanians in Ireland. Observatorio (OBS*), 5(2), 41-52

Meyrowitz, J. (1986). No sense of place: The impact of electronic media on social behavior. Oxford University Press.

Miller, S. M. (Ed.). (1987). The ethnic press in the United States: A historical analysis and handbook. Greenwood Publishing Group.

Neuman, W. R., Neuman, R. W., Just, M. R., \& Crigler, A. N. (1993). Common knowledge: News and the construction of political meaning. University of Chicago Press.

Fairclough, N. (1995). Critical discourse analysis: the critical study of language. New York: Longman.

Parham, A. A. (2004). Diaspora, community and communication: Internet use in transnational Haiti. Global Networks, 4(2), 199-217.

Shi, Y. (2005). Identity construction of the Chinese diaspora, ethnic media use, community formation, and the possibility of social activism. Continuum, 19(1), 55-72.

Shi, Y. (2009). Re-evaluating the alternative 'role of ethnic media in the US: the case of Chinese-language press and working-class women readers. Media, Culture \& Society, 31(4), 597-616.

Silverstone, R. (1999). Why study the media?. Sage.

Sun, W. (2002). Leaving China: Media, migration, and transnational imagination. Rowman \& Littlefield Publishers.

Sun, W., \& Sinclair, J. (Eds.). (2015). Media and communication in the Chinese diaspora: Rethinking transnationalism. Routledge.

Tellis, W. (1997). Application of a case study methodology. The qualitative report, 3(3), 1-19. Van Dijk, T. (2000). New (s) Racism: A Discourse Analytical Approach. II In Simon Cottle (ed.) Ethnic Minorities and the Media. 


\section{icrhs}

\section{4th International Conference On Research In}

HUMANITIES \& SOCIAL SCIENCES

Vertovec, S. (2004). Cheap calls: the social glue of migrant transnationalism. Global networks, 4(2), 219-224.

Wong, A. (2017). Transnational real estate in Australia: new Chinese diaspora, media representation and urban transformation in Sydney's Chinatown. International Journal of Housing Policy, 17(1), 97-119.

Yin, H. (2015). Chinese-language Cyberspace, homeland media and ethnic media: A contested space for being Chinese. New Media \& Society, 17(4), 556-572.

Yin, R. K. (1994). Case study research: Design and methods, London. Ed. Sage Publications.

Zhang, K., \& Hao, X. M. (1999). The Internet and the ethnic press: A study of electronic Chinese publications. Information Society, 15, 21-30.

Zhou, M., \& Cai, G. (2002). Chinese language media in the United States: Immigration and assimilation in American life. Qualitative Sociology, 25(3), 419-441. 